\title{
A Trick of the Light
}

Winter-

\section{The Darkest Day: December 21}

This is what the Yukon plays with: light and your understanding of it; light and its effect on you. Today, on the solstice, light will be slant, pearly, pale blue with a smudge of gold rubbed into it. Even at high noon, the sun's brightness is more like candlelight. Imagine a hollowed-out egg with a tea light burning inside. Or a candle glowing from underneath ice.

Today I walked through the woods to the pond. I make this walk most days. Behind my house there is boreal forest, criss-crossed with trails. It is easy to imagine that there is nothing human-made on either side of these woods, that it is forest all the way to the North Pole once I leave my backyard. Hinterland.

Some of the trails are wide enough for two friends to walk shoulder to shoulder; some are so narrow that branches tap their bony fingertips against my coat as I pass. I set out from my back gate and listen to myself for a sense of which kind of trail I am looking for. Often I crave the feeling of the black branches crossing over my head and sectioning the luminescent sky into puzzle pieces. Sometimes I want the openness of the frozen pond. 
On brighter days, the pond feels like a wide glass bowl that the weak buttery sun has been poured into. I walk around and around the flat bottom of the bowl, turning my face to find the faint light. It feels good to squint, or at least to go through the motions of squinting, pretending I need to.

We call solstice the shortest day of the year, but that really means it is the darkest day. It is as long as any other-it's just that most of its twenty-four hours will be experienced as a form of night. A long night of many shades and depths.

It is minus thirty degrees Celsius and Christmas. What does thirty below feel like? It feels shocking, slow, and clean. When you breathe in, it is almost like swallowing ice-cold vodka or aquavit that burns as it slides thickly down your throat. There is a sharpness to the in-breath, followed by a slightly softer, warmed exhale.

In minus thirty, when I go for a walk, I wear long johns, thick jogging pants, and snow pants; mohair socks and heavy, thick-soled, insulated winter boots; a long underwear shirt, a turtleneck, a wool sweater; a parka with fox fur trim; two toques (one tight and one loose with ear flaps); a wool scarf. And then I pull the hood of my parka up and button to the top and feel the soft fur stroke my cheeks. I walk through the woods pleasantly warm in my layers, but I feel swaddled and fat. I move stiffly. It takes a moment to adjust to this robot-like walking. Once I slow down, I feel more fluid, less crunchy.

You can rely on a white Christmas in the Yukon. In fact, you can rely on a Christmas-card-perfect white Christmas. The clean, bright snow layers on the firs and spruces is like mounded white icing on a gingerbread house. Snow underfoot is soft and powdery, not slushy and brown, or stale and crusted.

There is a feeling of being in a good place at this time of year. It is a time when the Yukon shines. Whitehorse is a small city, and while it has its fair share of box stores and independent shops, consumerismin general-generates a mere background hum. People move at a brisk, but unstressed pace. You are bound to run into someone you know. 
People pause, talk, laugh, in their thick coats and mittens. A towering Christmas tree at the end of Main Street has been strung with tiny lights.

Of course, I am lucky to see it this way. Everywhere there is poverty, including this town. I see people on Main Street looking hardfaced, ragged. A pimply-faced man staggered across the intersection the other day and yelled to me: "Miss! Miss! I just got punched in the face! I can't even smile!" He was wearing sneakers, barely held together with tape, on a minus 25 day.

Does he sense this joyful energy in the air at Christmas? I don't know what it is like to feel what he is feeling. I don't know if the energy I feel is universal or something that I have tuned into, like an available radio station, or if it is something I have created and carry around with me, like an inner lighthouse, a candle inside my ribs.

\section{Over Winter's Crest: Early January}

Seasons are actually micro-seasons. Winter is not just winter. There is early winter, with the first metallic whiff of snow in the air long before it lands on the ground like dust and melts or blows away within the hour. There is mid-winter, the darkest point when you can still feel autumn at your back and Christmas at the end of your nose. And now there is the point just over winter's crest, as though we have not just been moving forward in linear, chronological time, but also climbing up time, up over the dark side of the mountain of the year and now downward on the lit side, down into spring though we cannot see it yet.

The darkest day has passed and each day has seven more minutes of sunlight. The sun creeps a little higher into the sky and emits a more powerful light. I feel it in my eyes, the shocking glare of it, as I step through a dark wooded path into a clearing and the colours around me change from the deep blues and violets of shaded wood to gold, neon pink, and electric blue. It is breathtaking, this light and the hues it illuminates - and the contrast between the shadows and the light. It is this contrast that defines winter's crest. Instead of a steady palate of 
silvers, whites, blues, creams, and greys, we now have bright yellows against bold blues. This contrast is like a splash of cold water on your eyes first thing in the morning. It signals the body to wake up.

TODAY, THE SNOW IS NOT WHITE. IT IS A PATCHWORK OF BUTTERY yellows and whitish golds in the unshadowed places, and periwinkle to cadet blue in the shallow indentations left by boot prints, dog paws, and ski tracks. In fact, it is the exact shade of blue I would like to paint my kitchen. (I imagine myself describing this to the paint clerk at Home Hardware: "You know, the colour of the shadows on Patty's Pond at about noon on a brilliantly sunny day in the first week of January." They would either nod knowingly or stare at me alarmed.)

The sky is cloudless, unmarred even by the milky-white trails of airplanes. I walk with my head tipped back, filling my eyes with this thick, flawless swath of robin's egg blue. At the horizon (which is hard to pinpoint here because of the mountains and trees, but you can find pieces of it if you really set your mind to it), the blue becomes so light it is almost white. Then the colour deepens slightly as you look higher into the sky, into arctic blue, then columbia blue, then cerulean, sky, cobalt. Or these are the names we have given these variations in blue. They are smudged together, softened and blending one shade to the next. I imagine myself inside a bird's egg looking up at the sphere encapsulating me.

The bare birch-tree trunks show dramatic contrast, as well. The sides that present themselves to the sun are bright as brass. They look so dry and brittle, yet at the same time I can sense them warming and softening to the sun. On their backsides, they are brown-purple, cold to the touch, waiting for the sun to circle around.

The trick to not becoming a dry, brittle birch tree in winter is a sport I call extreme moisturizing. I spackle and massage moisturizer into my face and hands several times a day. Lanolin, which is used to keep nursing mothers' nipples and cows' udders from cracking, is thick like vaseline but a bit silkier, and it melts into the skin more smoothly. I rub it into my lips and cheeks before I go outside. You would think 
I'd look like a lacquered table, but I don't. My layers of lanolin, creams, and oils sink into my skin and I think soften it, render it sheeny and patinaed like an oiled leather saddle or polished wooden table. At least, I hope so. There are things I tell myself, since moving here.

OUT FOR A SKI ON THE MOUNTAIN TRAILS TODAY, AROUND FOUR o' clock. The sky is full of soft, whitish, pinkish, bluish light. It is all one colour-no watercolour streaks or blots. It is as though someone has carefully mixed a drop of fuchsia and a drop of cerulean into a watery white and swirled it.

I have never seen the snow as it is right now. There is a fine fresh skin of powder on top of older, denser snow. The flakes are tiny-not the chunky, sea salt variety, more the texture of sugar in the sugar bowl-and they have a moister look to them, though it is certainly still powder and not slush. I cannot find the sun in the sky, but everything around me is illuminated softly. In fact, it seems as though the source of light is coming not just from somewhere slightly above the treeline, but from below the snow, as though a powerful white searchlight-like the beam from a lighthouse-is shining up from underground.

Like the sky, the snow is a watery, translucent light, tinted pink. Then I turn my head, or swoosh forward on my skis, and it is tinted violet. Then aquamarine. It is magnificent, this light show. I am on a narrow trail in an alpine forest on a low mountain at sunset in January and the light is performing.

If you love nature, if you love to spend time outdoors quietly, observantly, you will know what I mean by this next idea: sometimes, if you are quiet long enough and at the right time, sitting outside in some thatch of itchy tall grass and spindly wildflowers or on a beach, alone, the water sliding toward your bare toes and then peeling back, flipping pebble end over end, if you are quiet long enough, sometimes nature appreciates you back and puts on a little show, demonstrates one of its tricks for you. A trick of light or water or wind. There is nothing to do about it except watch for as long as it is willing to show you, and then walk away when it is done, knowing that you have been 
given something rare and beautiful-worth more than any object you might purchase to have that feeling of owning something of beauty. And then, if you're an artist, you try in some way to re-create it. Or if you're a parent, you slip the feeling into your pocket, take it home to your children and whisper it into their ears while they sleep.

OUT FOR A WALK TODAY, THE SKY LIKE PEWTER AND THE AIR STILL as a stone. I am not out for these walks alone. I always have my dog. Levon came to us from the woods. A puppy who had been abandoned, most likely, and set out into the forest. That is something that happens up here, unfortunately.

A dog-sledder friend who lives out of town noticed a small white puppy running around her property. He would only get close at night, when she was out of sight, to eat the food she left out for him. He'd get eaten by a coyote or die of cold or hunger if he didn't let her trap him, she thought.

After a few weeks of watching each other carefully, she managed to trap him and brought him into her cabin where he immediately collapsed on a heap of blankets in a laundry basket, fast asleep. She called me because she knew I wanted a dog, and a few hours later I walked into her little cabin, sat down beside him, and we have not been very far from each other ever since.

If you are a dog person, you might understand how I feel about Levon. Some part of me is not very good with humans-most of me likes them very much, but some part finds all the talking, the maintenance, the social niceties, tiring and confusing. A high school teacher once told me he thought I came from a futuristic society where all people were kinder, and more sensitive, to each other. That's very flattering, and I don't know if it applies to me. But I know that dogs come from that place.

Levon likes to rest his chin on my arm when I am driving. If allowed up on the bed, for a treat, he spoons into the back of my knees and keeps me warm. When I have a flu or a cold, when I was pregnant and so nauseous sometimes all I could manage was lying very still, 
Levon stayed close. He feels what I feel and I feel what he feels. We are like Eliot and E.T.

So we walk. Levon running a hundred metres for every ten I walk. He lopes around, darting through the snow, disappearing into thickets, and then popping back onto the trail in front of me. He goes about fifteen seconds before checking in on me. If he's gone much longer, I let out a lazy whistle and he pops his head out of a bush to let me know he's just fine. If he's gone a really long time, like two or three minutes, I let out a sharp whistle and he comes galloping, tongue hanging from his jaw and curved like a ladle, and I know he has found something of interest-another dog, a bone, or something rotting and stinking to roll in.

Once he didn't come when I whistled. I was on a beach in Ontario and I called and called, but no Levon. I had just bought him a halter so that when I walked him on leash I wouldn't pull on his neck. I walked up and down the beach with my friends, looking for him. Then I saw a flailing white thing, writhing on its back near a collapsed stone wall. I sprinted and saw that the halter had caught on a piece of wire corkscrewing out of the wall. Levon had cut his leg trying to respond to my call. I figured out then that if he didn't come when I called him, it meant he needed my help.

The second time he didn't come was about a week before I had my baby. I was walking through the woods and passed the pond that had just crusted over with new ice when I realized I hadn't seen Levon in a while. I called for a few minutes and nothing. So then I knew he'd gotten into trouble and my gut said he had gone through the thin skin over the pond. If I hadn't been pregnant, I wouldn't have hesitated to run in and fish him out. It wasn't that cold; I was only a few hundred metres from home and had my cell phone; the pond is not deep and I am a very strong swimmer. But instead I ran for the pond while calling home on my phone for help and shouting to Levon that I was coming. All I could do was hope he could hear me: "Come on, Levon! Come on! Keep trying!" I couldn't see him and he couldn't see me, but I was hoping that he could hear my voice. Then, after about ten minutes of this running and shouting and feeling afraid, he sprinted up the path 
towards me. I felt foolish for getting so scared and for thinking he'd gone through the ice-until I hugged him. He was soaking wet and frigid.

But most of the time, thankfully, we just walk. If an unfamiliar animal has crossed our path, Levon stops and refuses to go forward. That's when I know to turn around and keep my eyes open for bears. If we pass any open water, even just a puddle, Levon runs for it and splashes through, alight with happiness.

On these winter days, he trots ahead of me, so much joy in his gait, in his bounding up the hill, in the swinging of his head when he looks back at me as if to say, "Here we are, you and me, and another fine day."

I WAS BACKING OUT OF A STEEP, SLUSHY DRIVEWAY THE OTHER DAY. I hate this driveway. It backs onto a busy road and there's no way out but tail-end first. I shot down backwards at the first clear sign and had just reached the lip of the driveway where all the snow had been bunched up along the curb from the snowplow, when a car zipped by and I had to hit the brakes and thunk. I was stuck. I tried the old Canadianwinter standby manoeuvre of rocking back and forth. No luck. I opened the car door and stepped outside and did that thing where you look at the snow you know is swallowing your front tires, and shake your head, and appear to be keeping your cool and expertly appraising the situation, even though on the inside I was thinking, shit. I have no idea how to get out of this situation.

About three seconds later, a transport truck approaches, pulls over, and two guys jump out. "Need some help?" They dig away at the snow with their boots, they throw their combined weight against the hood, the tires spin and chew their way down deeper. Another truck stops. Then another. A driver on the road puts his blinkers on and calls out to us that the road is clear. Another driver in a mammoth truck rolls down his window and yells, "I used to have a shitty little Toyota too! Not anymore!" People laugh. Someone says, “Okay, rock it!" and I start rocking, then "Gun it!" and I gun it. My little Toyota jumps free and slides out onto the road, which is being blocked in both directions by drivers who raise a hand or a fist in triumph, and I yell thank you out the window, and these guys, with their big, abused trucks who 
stopped within a matter of minutes to help me, get back in their seats and drive off.

Not one of these guys would smile at me and wave hello and look me right in the eye if I passed them on the sidewalk. But they wouldn't drive past a car stuck in a snowbank. And they wouldn't make you feel like an idiot for getting stuck or expect a medal for getting you out.

\section{The Dirty Grey Cloth: Early February}

Beginning of February and we have passed into the part of winter that plays with your mind, makes everything seem darker. General morale is low. You see it while waiting in line at the grocery store, feel it as you drive your car through tricky intersections-just a bit more impatience, a tight, foggily angry expression on faces, a sink in posture.

For the past few weeks, a dirty grey cloth has lain on top of our town. I found myself getting frustrated with it while washing the dishes, looking out into the smudgy blot of it and thinking, why here? Why do we live here? I'm not the only one. At a potluck, friends talk of travel and home provinces with a certain edge to their voices. We hear it has been sunny all month in British Columbia and no one wants to talk about it.

That's a funny custom here: people and how they talk about the weather. If you love it up here, I mean, if you are one of those aggressively-in-love-with-the-Yukon sorts (those who have fled some dull city back east and made a new home here, as opposed to those who are from here and just love it in an easy, laid-back way) then when it is sunny and mild, you talk about the weather a lot-especially about how much better it is here than anywhere in Canada at the moment (except for BC, which somehow doesn't count and you don't talk about unless they've had a long, rainy stretch) - these kinds of Yukoners do not like rain. If, however, the weather has been grey, cold, drizzly in the Yukon which, it feels to me, it often is, then the topic of better weather elsewhere is forbidden. You might bring up typhoons in Indonesia or earthquakes in California, but never the unrelenting sunshine of Ontario summers, the early spring in Saskatchewan, the warm, glorious Maritime autumn. 
Yesterday, the rag was pulled clear off. Not a cloud. Incredible, electric blue sky, dazzling sun. You could feel a collective sigh. I went for a walk around the neighbourhood, where the trees of my forest paths would not block out any sun, and passed other neighbours, walking with their children or tinkering on something in their sheds or driveways. A wave or raised hand here or there. Not much, but still, I could sense a shift, a lightness in their movements. A lightness in mine. Sunlight changes us. Weather changes us. Patterns of weather create patterns of change in us.

Sometimes I wonder about that-how have the different places I have lived, and their different weather patterns, created new patterns in me? Surely, up here-where the light pulls such trickery, starves us and then feeds us a feast, challenges the boundaries of night and day-these changes are dramatic, unusual. I hope for the positive. I will believe it is for the positive.

\section{The Blue Hour: February 12}

A walk tonight, around the neighbourhood, during the blue hour. To the east, the sky looked ominously grey, like the background behind the evil villain's castle in a children's cartoon. To the west, a smudge of cloud wisped at one corner to reveal a faintly luminescent lilac-grey, the same shade as the inside of a mussel shell.

The blue hour happens about six o' clock now. Already, we have gained back enough light that this feels miraculous, breathlessly fastto walk at six and still see clearly the colours of houses-make out yellow doors and purple trim.

Houses in the Yukon make me think of hobbit dwellings. They seem to slide into the earth-some of them actually are, as the ground shudders in slow motion, as it freezes and thaws. The first house I stayed in here had floors so slanted you could set a tennis ball down in the living room and it would tumble cheerfully toward the kitchen.

Materials can be hard to find up here, just like everything else, so in my neighbourhood Yukon houses often look patchworked together. A slab of plastic siding, a wall of wood, a slapdash building in the back. Outbuildings are very popular. A lot of people snap up those ugly 
makeshift storage tents, but others build beautiful tiny wooden rooms, full of window and light. I imagine writers, musicians, toiling inside by candlelight.

People paint their houses Crayola colours-magenta, canary yellow, royal blue, periwinkle. Yards tend to be small, grass is scrubby here, and everyone's got a greenhouse they've constructed out of old, lead-paned windows.

And dogs everywhere. Off leash, running from the yards to meet us as we pass and taunting Levon whom I keep on a leash when we walk on neighbourhood streets. (Multiple bylaw signs remind us to leash our dogs, but Yukoners tend to extend a calm middle finger to by-laws.) Levon twirls full circles, leaping at the other dogs. They dart in and dart back, then trot away. There is a complex pecking order among the dogs here that I have no business trying to understand.

\section{A Particular Kind of Loneliness: February 28}

Downtown today, a busy café. The sun has been out for a few days now and temperatures have been sitting comfortably above zero. Moods are on the upswing. If it weren't for the mountains, we'd be flooded in sunlight right now. Sometimes I want to sweep my arm across the valley, knock the mountains from the tabletop, give us all a little breathing room. Clear the shadows.

The mountains make me feel as though we live on an island. An island of land surrounded by rock and snow. We can feel like an island community-cut off from the rest of the country by so much unnavigable rockiness. This has its pluses and minuses.

I remember when I lived in Nova Scotia I felt this way for the first time-as though certain busy cities, Toronto, Montreal, Ottawa, New York, are hubs from which all manner of energy emanates and Nova Scotia was far enough removed from the hub that I could actually feel the protective barrier of space.

It's like when you live in a home with a lot of people, and the living room downstairs houses the television, the stereo, the board games. The family drama unfolds there and visitors pass in and out of this room and it gets crowded and loud and interesting and beautiful. 
That's Ontario, maybe. Nova Scotia, in my opinion anyway, is in the attic. I'm still aware of what is happening down in the living room-I hear the occasional crack of laughter, the thump of bass-but I am buffered from the direct experience.

To be in the Yukon, for me, is to be up on the roof. I barely hear a thing from below; I miss out on the music and the pizza and the neighbours dropping in. I hear instead an incredible stillness. The air is astringent. The view is extraordinary. It can be lonely. It can be medicinal, this particular kind of loneliness.

I wouldn't want to stay on the roof too long-it isn't the right medicine for me to be taking long-term-but now and then it is a good place to live, to remove oneself from feeling as though the hub, where all the action is, is the only place to be, as though it defines your life for you. Up here, the quietness, the loneliness, allows a certain quality of thought, a chance to view things from a different angle and put it all into perspective. And it allows the chance to deeply, achingly miss people and noise and chaos. That is a useful kind of loneliness. 